\title{
13. OPAL PHYTOPLANKTON REMAINS AT DSDP LEG 40 SITES
}

\author{
Hans-Joachim Schrader,' Geologisch-Paläontologisches Institut und Museum \\ der Universität Kiel, Olshausenstrasse 40/60, D 23 Kiel, F.R. Germany
}

\section{INTRODUCTION}

During Leg 40 of the Deep Sea Drilling Project, six sites, 360 through 365 (Figure 1), were drilled in the Cape and Angola basins on the eastern Atlantic continental margins of southern Africa. Opal phytoplankton remains, sponge spicules, and phytoliths were studied under the light microscope. Samples were provided by the shipboard party who routinely sampled every section of every core. Sample preparation followed the standardized methods of Schrader (1974) for semiquantitative study. References for determination of abundance and preservation can be obtained from Schrader and Fenner (1976). Diatom zonation, summarized in Figure 2, is that of Burckle (1972) and of Schrader and Burckle (in press); the proposed correlation (loc. cit.) to the paleomagnetic stratigraphy and to other standard microfossil zonations is the initial one in Schrader and Burckle (1976).

No detailed taxonomic investigation was done on Leg 40 samples, since most of the species are well described in Schrader (1973, 1974a, b), Koizumi (1973, 1975), Kolbe (1954), Burckle (1972), Hustedt (19301959), and Simonsen (1974).

\section{RESULTS}

All samples studied from Sites 360, 361, 363, and 364 were barren of any phytoplankton opal skeletons and land-derived opal particles.

\section{Site 362}

Site 362 (Holes 362 and 362A) is located on the Abutment Plateau of the Frio Ridge segment of the Walvis Ridge where the ridge adjoins the continental margin of southwest Africa, and was drilled in 1325 meters of water. The recovered sediments have been subdivided into four lithological units ranging from Holocene to lower Eocene (see Chapter 3, this volume).

Lithologic Unit 1, a diatomaceous marly nanno ooze, covering the interval from Core 1 through Core 26 , yielded a rich and diverse diatom flora. Results are tabulated in Table 1 and summarized on Figure 3. Samples 362-7-5, 79-80 cm and 362-17-6, 79-80 cm consisted almost entirely of displaced fresh-water diatom assemblages with abundant Melosira granulata, Stephanodiscus astreae. Associated with the fresh-water diatoms were phytoliths. Abundance of phytoliths is

\footnotetext{
'Present address: School of Oceanography, Oregon State University, Corvallis, Oregon.
}

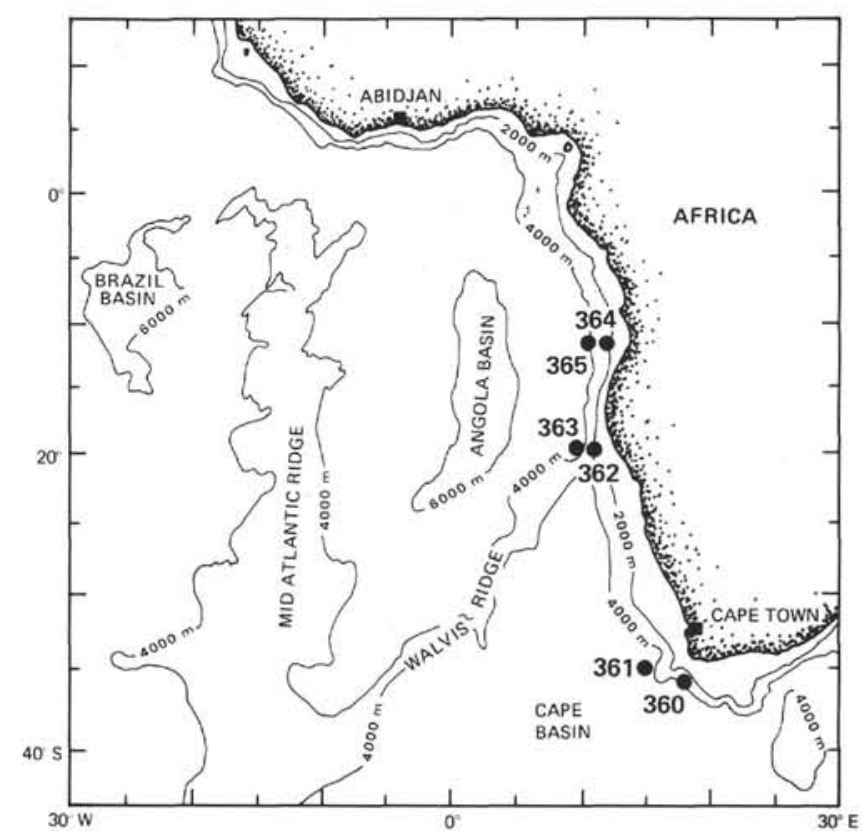

Figure 1. Location of drill sites on the continental margin of South/Southwest Africa.

tabulated in Table 1. Sample $362-5-5,79-80 \mathrm{~cm}$ contained abundant fecal pellets filled with wellpreserved marine diatoms; the diatom assemblage of Sample $362-10-3,79-80 \mathrm{~cm}$ was strongly etched and showed an increase of "Liostephania" stages and corroded fragments. The occurrence of stratigraphically important species led to the following biostratigraphical subdivision (compare Figure 2). Interval 0-46 meters is placed in the Pseudoeunotia doliolus Zone of Burckle (1972). Interval 46-73 meters represents the Pliocene/Pleistocene boundary which could not be more closely defined. Interval 73-100 meters is placed in the Rhizosolenia praebergonii Zone of Burckle (1972), and interval 100-128 meters to the Nitzschia jouseae Zone of Burckle (1972), interval 128-134 meters to the Thalassiosira convexa Zone of Burckle (1972). The interval 134 meters through 330 meters either did not yield good stratigraphical marker species, and/or diatom assemblages were poorly preserved. Thus no biostratigraphic subdivision was possible using diatoms. The upper Miocene-lower Pliocene boundary should also be placed within this interval, since the sequence from 330 to 410 meters subbottom can be correlated to the Coscinodiscus yabei Zone of Burckle (1972). All samples below 410 meters subbottom (below Sample $362-27-1,79-80 \mathrm{~cm}$ ) were barren of diatoms. 


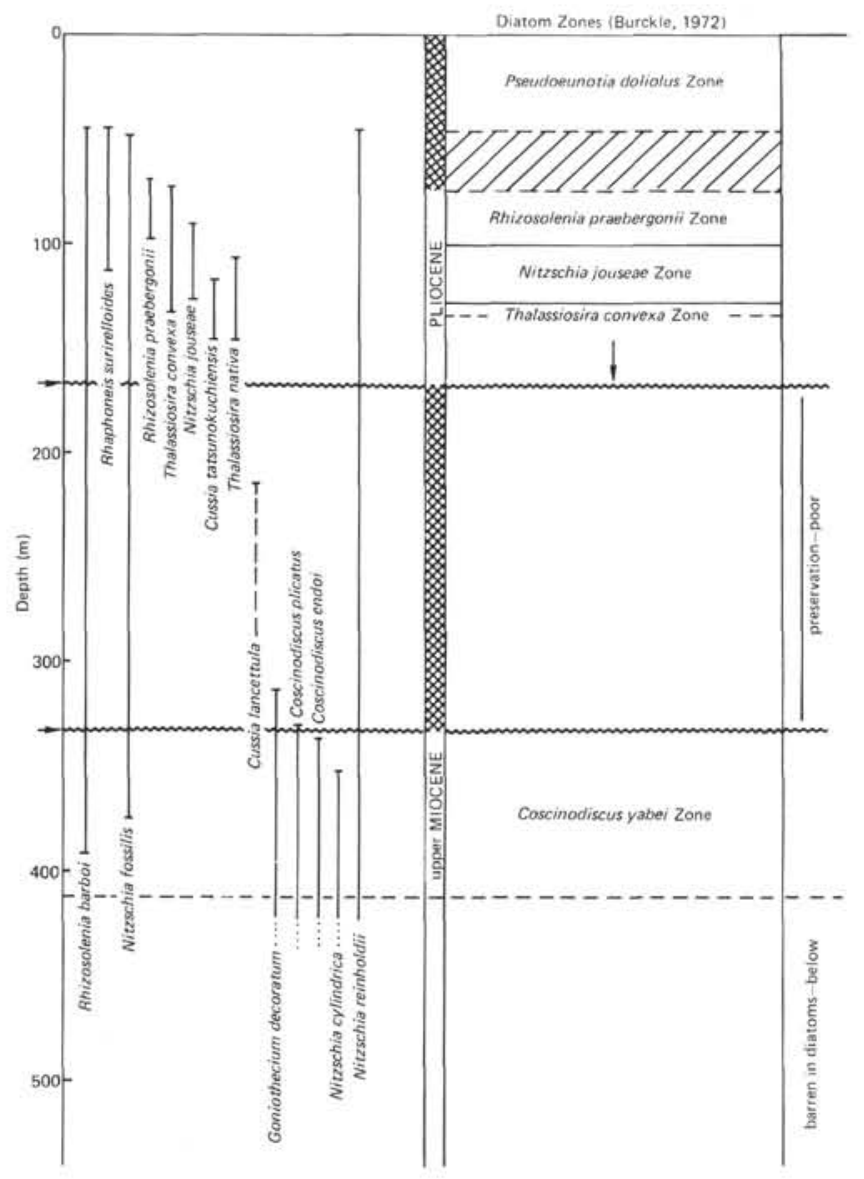

Figure 2. Ranges of selected diatom biostratigraphic indicator species at Site 362.

\section{Site 364}

Site 364 was targeted in the Angola Basin, landward of an abrupt marginal escarpment along the continental margin of southwest Africa and was drilled at a water depth of 2448 meters. Seven lithological units were recognized ranging from the Pleistocene to the upper Aptian. The only diatom-bearing sample (364-1-1, 79$80 \mathrm{~cm}$ ) contained a moderately well preserved Pleistocene assemblage.

\section{Site 365}

Site 365 was drilled in 3018 meters of water along the base of the eastern wall of a small cleft west of Site 364 . Five lithological units were recognized ranging in age from Pleistocene to upper Aptian (?). A well-preserved tropical diatom assemblage with Pseudoeunotia doliolus and Thalassiosira oestrupii was found in Sample 365-1$1,79-80 \mathrm{~cm}$. All other samples were barren in opal phytoplankton skeletons. A more detailed study with chemically untreated material was done on Samples 365-6-4, 5-6 cm (A), 365-7-1, 24-25 cm (B), and 7-2, 37$38 \mathrm{~cm}$ (C). Sample A contained no diatoms but wellpreserved radiolarians. Samples B and C contained pyritized diatoms which could be assigned to the following genera and/or species: Stephanopyxis aff. turris, Coscinodiscus aff. divisus, and Coscinodiscus aff. marginatus. An age assignment on the basis of these

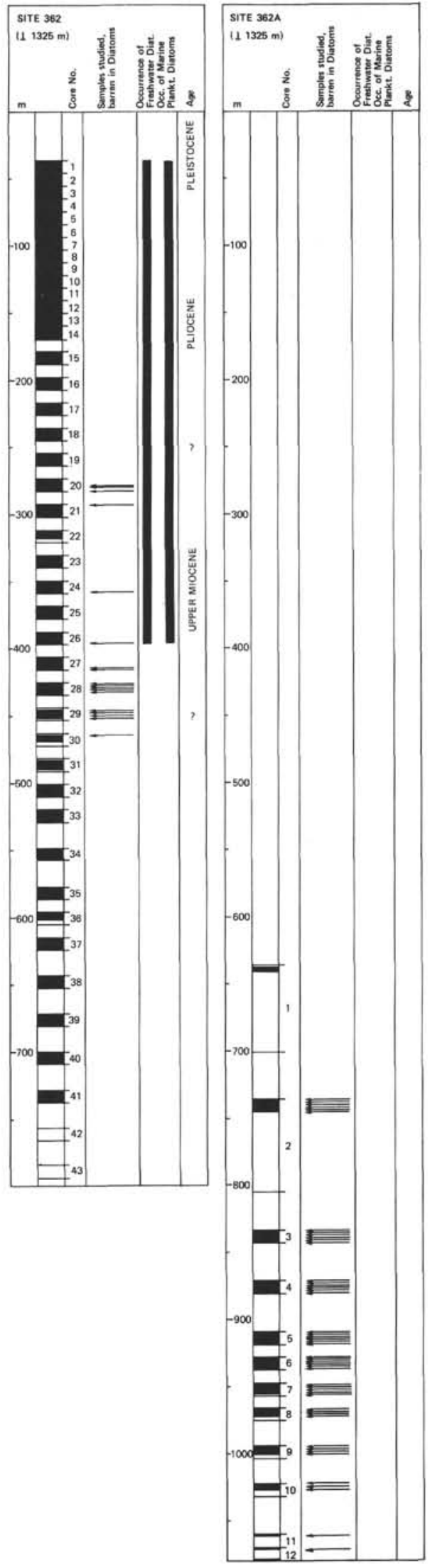

Figure 3. Site 362 summarys small arrows indicate sample positions within the cored/recovered section. 
poorly preserved individuals is impossible, but I speculate that this material is not older than Tertiary.

\section{DISCUSSION}

Diatomaceous sediments were found only within the upper Tertiary sediment sequences of DSDP Leg 40 drill sites, and only Site 362 had a significant number of diatomaceous samples. An upper Neogene section was obtained at Site 362 with poorly to well preserved marine planktonic diatom assemblages ranging in age from upper Miocene to the Recent. Assemblages consisted of tropical to subtropical species and can be correlated directly to the Standard Diatom Zonation established in the East Equatorial Pacific (Burckle, 1972). On the other hand, nutrient-rich surface-waters, which directly lead to high diatom production, did not influence the Walvis Ridge until late Miocene time. Associated with the increase in marine planktonic diatom production is an increase of displaced freshwater diatoms and phytolith remains. Further discussions on the coastal upwelling phenomena off Walvis Bay and of Cape Blanc will be found in the DSDP Leg 41 volume.

\section{ACKNOWLEDGMENT}

This paper was supported through the Deutsche Forschungsgemeinschaft and the National Science Foundation. I thank the Leg 40 scientific party for making this set of samples available

\section{REFERENCES}

Burckle, L.H., 1972. Late Cenozoic planktonic diatom zones from the eastern equatorial Pacific: Nova Hedwig., v. 39, p. 217-246.

Hustedt, F., 1930-1959. Die Kieselalgen Deutschlands, Österreichs und der Schweiz. In L. Rabenhorst Kryptogamenflora von Deutschland, Österreich und der Schweiz: v. 7, Leipzig (Akad. Verlagsgesellschft.).
Koizumi, J., 1973. The Late Cenozoic diatoms of Sites 183193. Leg 19 Deep Sea Drilling Project. In Creager, J.S., Scholl, D.W., et al., Initial Reports of the Deep Sea Drilling Project, Volume 19: Washington (U.S. Government Printing Office), p. 805-854.

1975. Neogene diatoms from the western margin of the Pacific Ocean, Leg 31 DSDP. In Ingle, J.C., Karig, D.E., et al., Initial Reports of the Deep Sea Drilling Project, Volume 31: Washington (U.S. Government Printing Office), p. 779-819.

Kolbe, R.W., 1954. Diatoms from equatorial Pacific cores: Rept. Swedish Deep-Sea Exped., v. 6, p. 1-49.

Schrader, H.-J., 1973. Cenozoic diatoms from the northeast Pacific, Leg 18: In Kulm, L.D., von Huene, R., et al., Initial Reports of the Deep Sea Drilling Project, Volume 18: Washington (U.S. Government Printing Office), p. 673-797.

1974. Proposal for a standardized method of cleaning diatom-bearing deep-sea and land-exposed marine sediments: Nov. Hedwig., v. 45, p. 405-409.

1974a. Cenozoic marine planktonic diatom stratigraphy of the tropical Indian Ocean. In Fisher, R.L., Bunce, E.T., et al., Initial Reports of the Deep Sea Drilling Project, Volume 24: Washington (U.S. Government Printing Office), p. 887-967.

1974b. Revised diatom stratigraphy of the Experimental Mohole Drilling, Guadalupe Site: Proc. Calif. Acad. Sci., 4th Ser., v. 39, p. 517-562.

Schrader, H.-J. and Burckle, L.H., in press. Marine diatom biostratigraphy, its correlation to other microfossil zonations and to the paleomagnetic record. In Riedel, W.R. and Saito, T. (Eds.), Symposium "Marine Plankton and Sediments," Kiel.

Schrader, H.-J. and Fenner, J., 1976. Norwegian Sea Cenozoic diatom biostratigraphy. In Talwani, M., Udintsev, G., et al., Initial Reports of the Deep Sea Drilling Project, Volume 38: Washington (U.S. Government Printing Office), p. 921-962.

Simonsen, R., 1974. The diatom plankton of the Indian Ocean Expedition of R/V "Meteor" 1964-1965: MeteorForschungsergebn, Reihe D, No. 19, p. 1-107. 
TABLE 1

Diatoms at Site 362

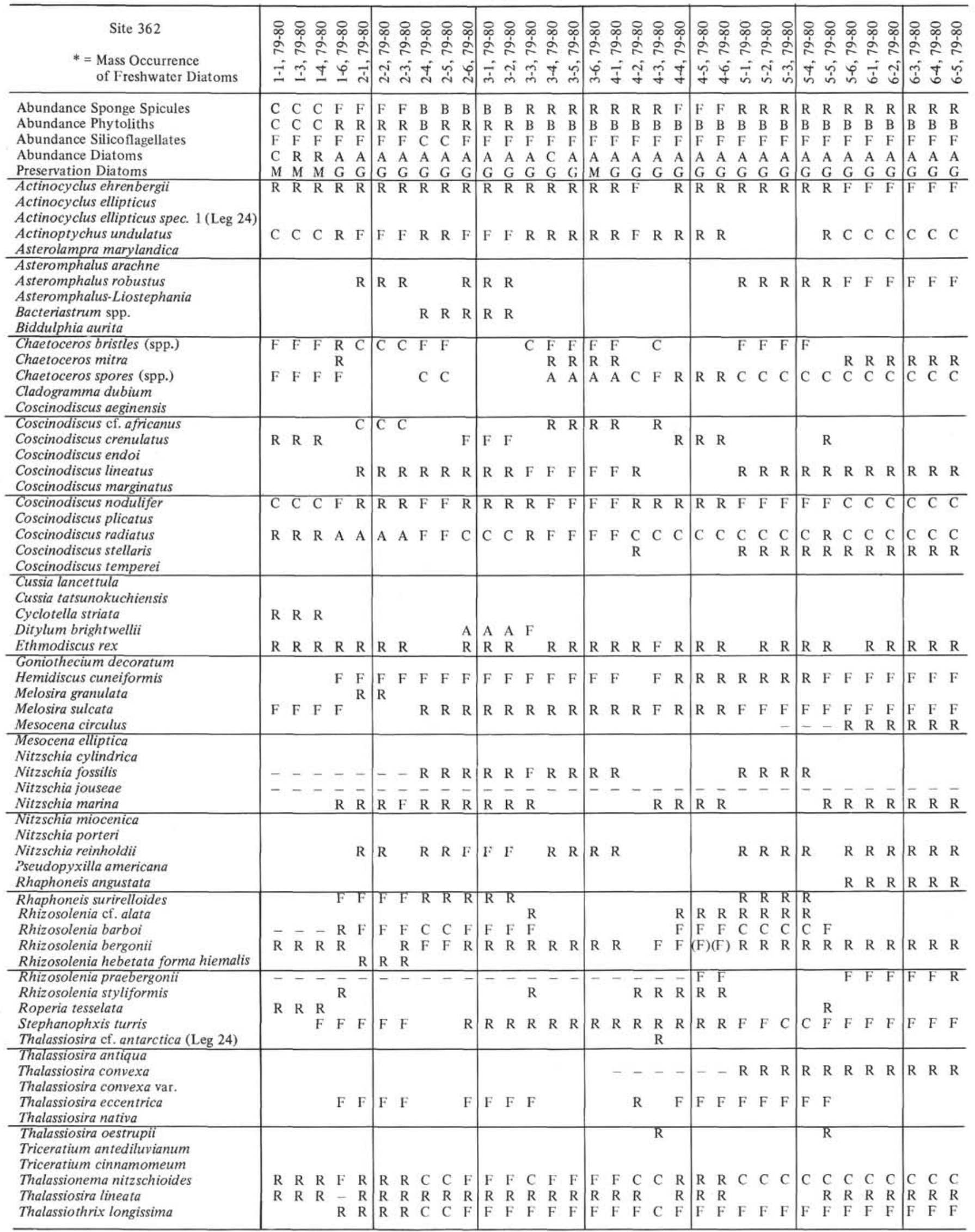




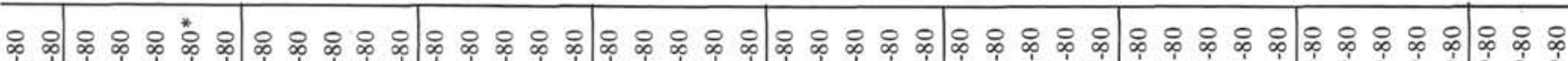

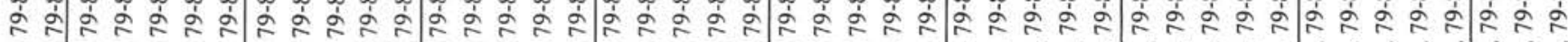

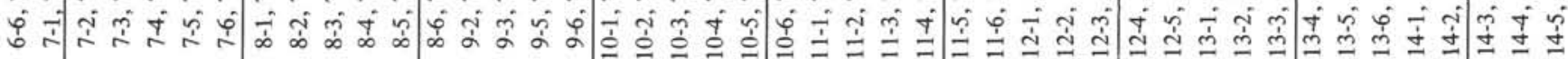
\begin{tabular}{lllllll|llllllllllllllllllllllllllllllllllllllll}
\hline$R$ & $R$ & $F$ & $F$ & $R$ & $R$ & $R$ & $F$ & $R$ & $F$ & $F$ & $F$ & $F$ & $F$ & $R$ & $R$ & $F$ & $F$ & $F$ & $R$ & $F$ & $F$ & $R$ & $F$ & $C$ & $C$ & $F$ & $F$ & $R$ & $R$ & $F$ & $F$ & $F$ & $F$ & $C$ & $R$ & $F$ & $R$ & $R$ & $R$ & $R$ & $R$ & $R$ & $R$ & $R$
\end{tabular} \begin{tabular}{ll|lllll|lllll|lllllllllllllllllllllllllllllllllllllll}
$B$ & $F$ & $F$ & $R$ & $R$ & $F$ & $F$ & $F$ & $B$ & $F$ & $F$ & $B$ & $R$ & $B$ & $B$ & $B$ & $R$ & $R$ & $R$ & $R$ & $R$ & $R$ & $R$ & $R$ & $R$ & $R$ & $R$ & $R$ & $R$ & $R$ & $B$ & $R$ & $R$ & $R$ & $R$ & $R$ & $R$ & $R$ & $R$ & $R$ & $B$ & $R$ & $R$ & $R$ & $R$
\end{tabular}

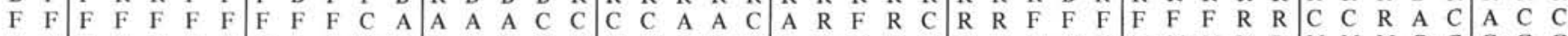
A A C A R A A C A F M G G G G M M M G G M G M M M G M P M M M M M M P P M M M G G G G

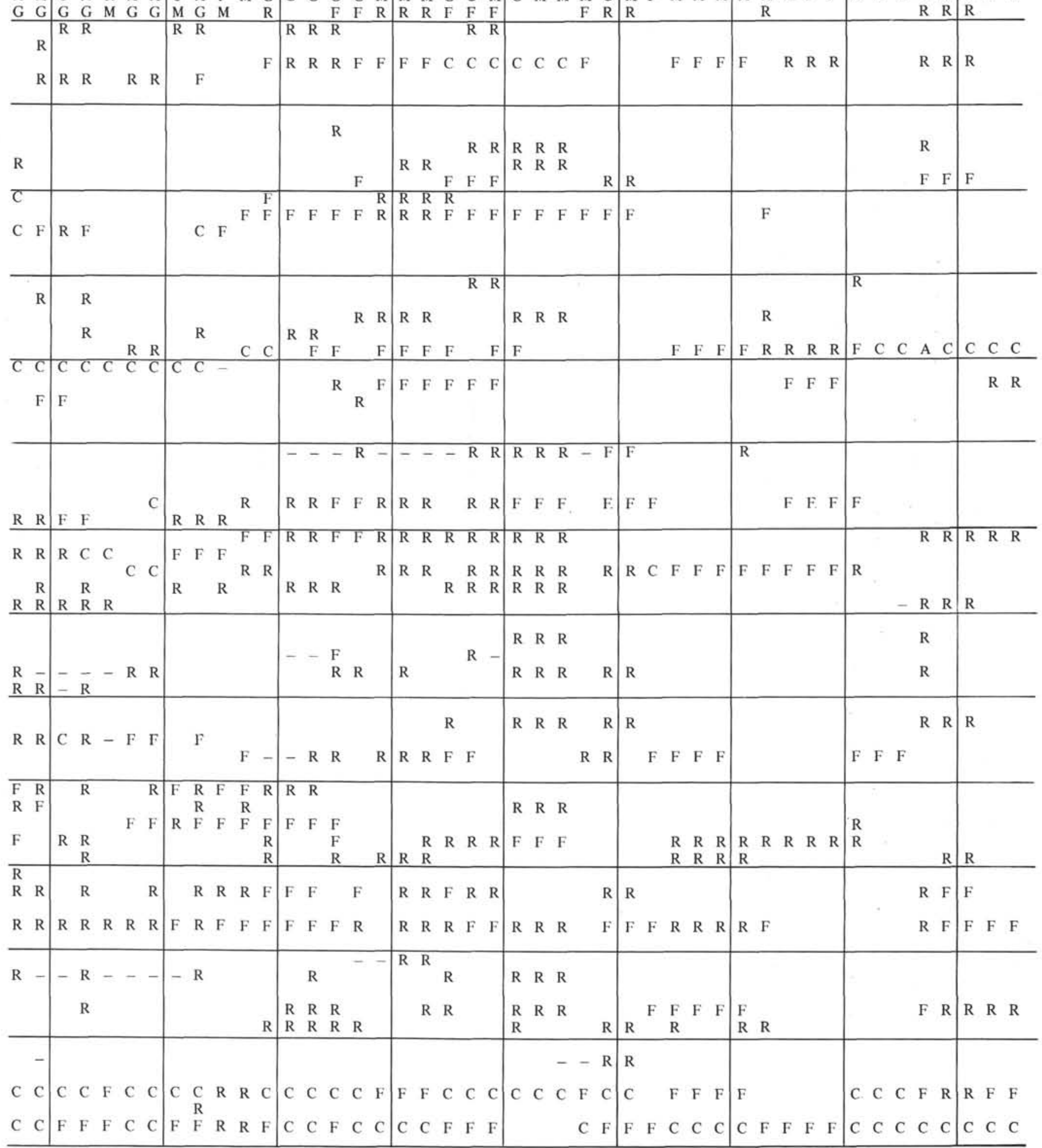




\section{H. -J. SCHRADER}

TABLE 1 - Continued

Site 362

* = Mass Occurrence of Freshwater Diatoms

Abundance Sponge Spicules Abundance Phy toliths Abundance Silicoflagellates Abundance Diatoms Preservation Diatoms Actinocyclus ehrenbergii Actinocyclus ellipticus Actinocyclus ellipticus spec. 1 (Leg 24) Actinoptychus undulatus Asterolampra marylandica Asteromphalus arachne Asteromphalus robustus Asteromphalus-Liostephania Bacteriastrum spp. Biddulphia aurita

Chaetoceros bristles (spp.) Chaetoceros mitra Chaetoceros spores (spp.)

Cladogramma dubium Coscinodiscus aeginensis Coscinodiscus cf. africanus

Coscinodiscus crenulatus Coscinodiscus endoi Coscinodiscus lineatus Coscinodiscus marginatus Coscinodiscus nodulifer Coscinodiscus plicatus Coscinodiscus radiatus Coscinodiscus stallaris Coscinodiscus temperei Cussia lancettula Cussia tatsunokuchiensis Cyclotella striata Ditylum brightwellii Ethmodiscus rex Goniothecium decoratus Hemidiscus cuneiformis Melosira granulata Melosira sulcata

Mesocena circulus Mesocena elliptica Nitzschia cylindrica Nitzschia fossilis Nitzschia jouseae

Nitzschia marina

Nitzschia miocenica

Nitzschia porteri

Nitzschia reinholdii Pseudopyxilla americana

Rhaphoneis angustata

Rhaphoneis surirelloides

Rhizosolenia cf. alata

Rhizosolenia barboi

Rhizosolenia bergonii

Rhizosolenia hebetata forma hiemalis

Rhizosolenia praebergonii

Rhizosolenia styliformis

Roperia tesselata

Stephanopyxis turris

Thalassiosira cf. antarctica (Leg 24)

Thalassiosira antiqua

Thalassiosira convexa

Thalassiosira convexa var.

Thalassiosira eccentrica

Thalassiosira nativa

Thalassiosira oestrupii

Triceratium antediluvianum

Triceratium cinnamomeum

Thalassionema nitzschioides

Thalassiosira lineata

Thalassiothrix longissima ,

(1)

○ হ่

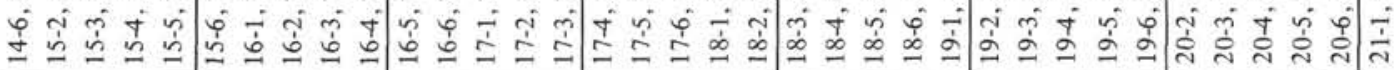

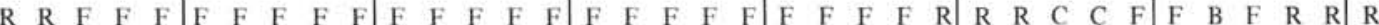

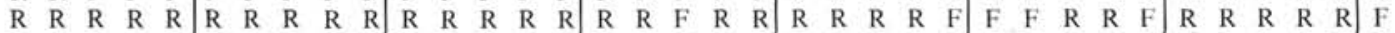

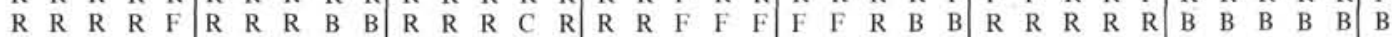

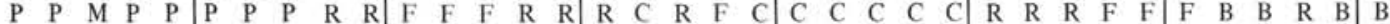

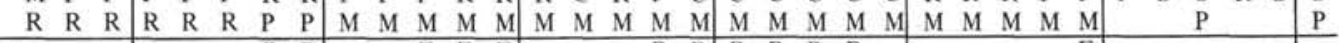

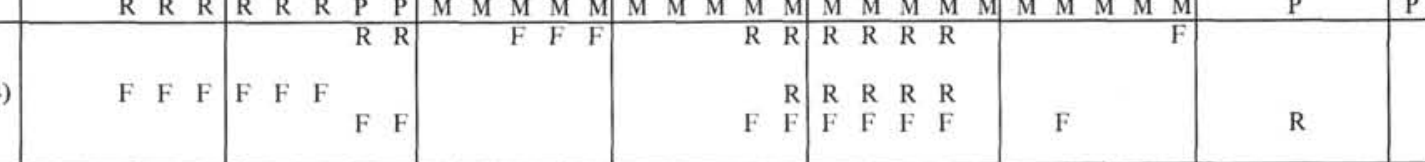

\begin{tabular}{llllll}
\hline F F F F F F & F
\end{tabular}

.

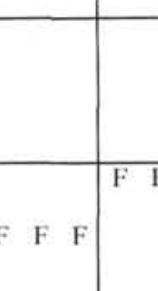

\begin{tabular}{|c|c|}
\hline $\mathrm{R} \quad \mathrm{R}$ & \\
\hline F F & $\mathrm{F} F \quad \mathrm{~F}$ \\
\hline
\end{tabular}

R

$\mathrm{R}$

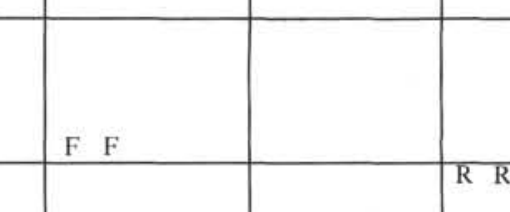

\begin{tabular}{ll|llll} 
& & & & & \\
& & $R$ & $R$ & \\
\hline & $F$ & $F$ & $C$ & $C$ & $F$
\end{tabular}

\begin{tabular}{ll|lllllllll}
$C$ & F & F & F & F & F & \\
R & R & R & R & R & R & R & F & F
\end{tabular}

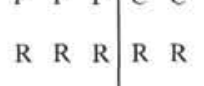

\begin{tabular}{|l|l|l}
\hline & \\
\hline & \\
\hline & $R$
\end{tabular}

(n)


TABLE 1 - Continued

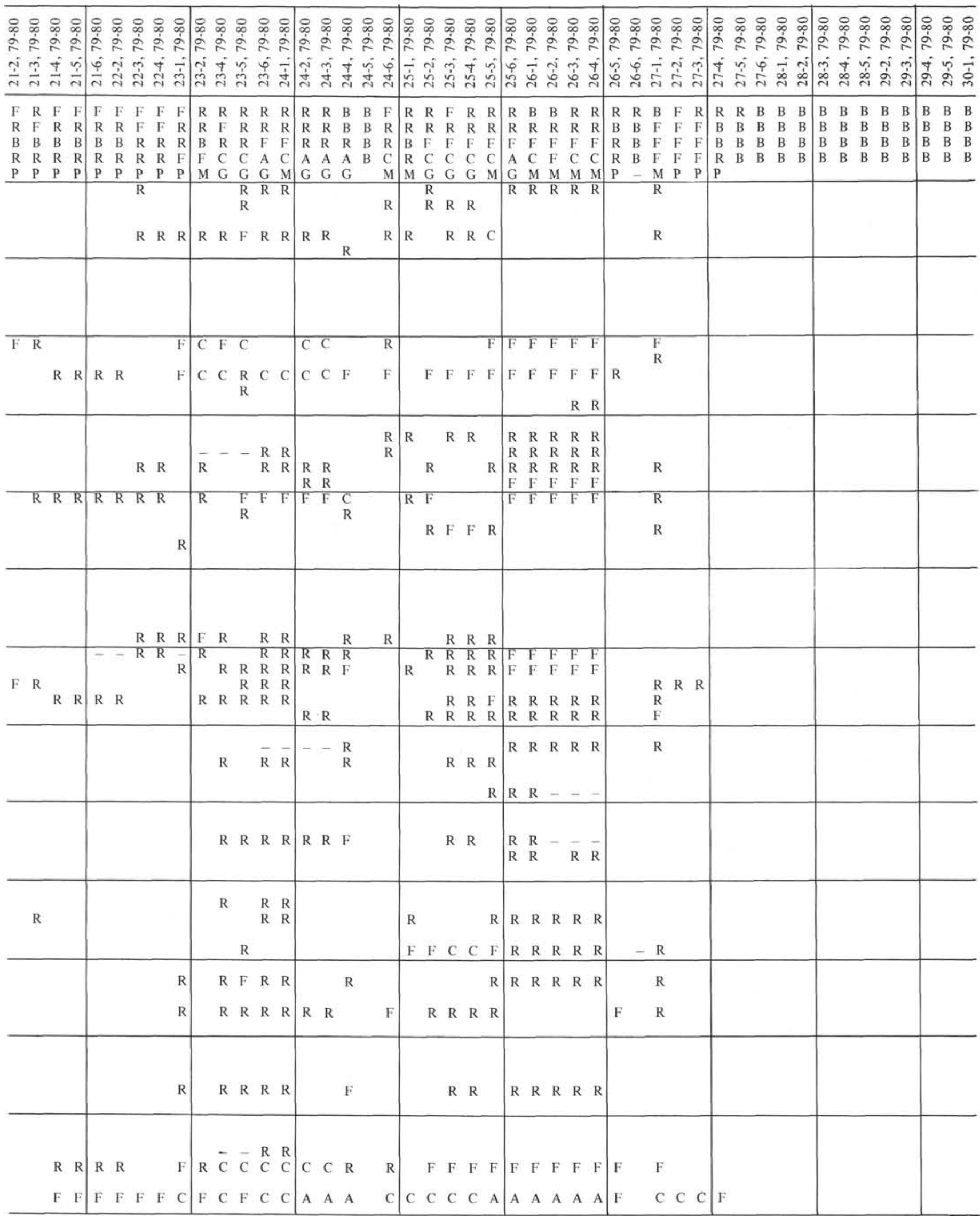

